\title{
Radhe Krishna Temple of Baroh, Kangra: A Photo Journey
}

Sapna Dogra

PhD from from Jawaharlal Nehru University. Email: sapnardm@gmail.com

In this photo essay, I want to show the spectacular beauty of the Baba Baroh Temple of Kangra through some of my photographs.Located in Baba Baroh, a tehsil of Kangra district of Himachal Pradesh, $45 \mathrm{~km}$ away from Dharamshala City.

Radhe Krishna temple of Baba Baroh is the most famous pilgrim spot for the rural population. A lack of hotels, guest houses and restaurants in the area are some of the reasons that this temple is not on every traveller's list that comes to Kangra. A large number of other smaller temples can be found around Baroh but are of negligible historical and architectural importance. At present, one big marble temple is standing here and is spectacular in beauty. The breathtaking beauty of the temple can be gauged by the fact that the temple (made purely of white marble) stands tall atop a hill surrounded by snow-capped Dhauladhar range around it.

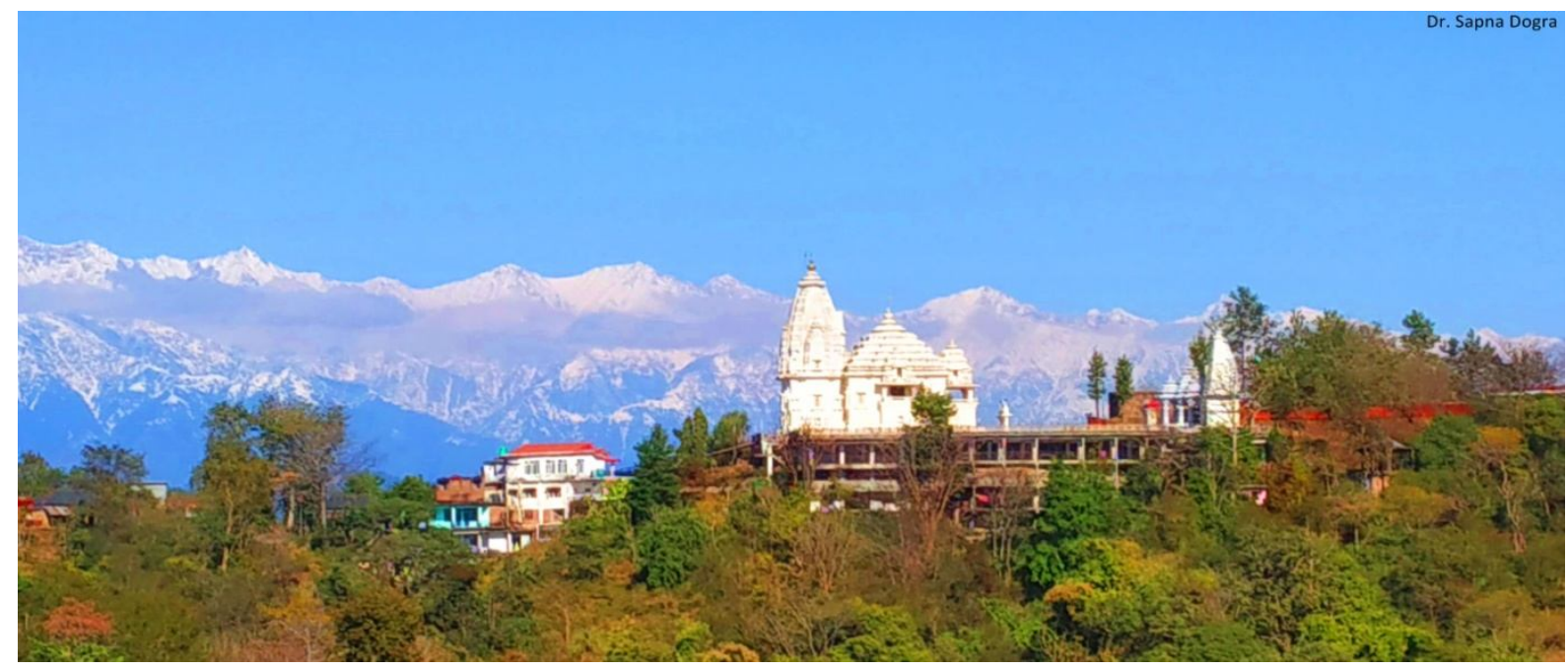

Distant view of the temple surrounded by the breath-taking snow-capped Dhauladhar range of the Himalayas.

Baroh is a small village in the Nagrota Bagwan Tehsil in Kangra District of Himachal Pradesh State, India. It comes under Baroh Panchayath. It is located approx. $45 \mathrm{~km}$ towards South from District headquarters Dharamshala and approx. $206 \mathrm{~km}$ from State capital Shimla. Local folklore says that during the reign of Sikhs, two saints, Baba Baroh and Baba Fattu came to Kangra. They were later helped by the local kings of Kangra and set up their temples in the area. The place takes its name from the saint Baba Baroh. As one travels from Ranital $12 \mathrm{kms}$

(C) AesthetixMS 2019. This Open Access article is published under a Creative Commons Attribution Non-Commercial 4.0 International License (http://creativecommons.org/licenses/by-nc/4.0/), which permits non-commercial re-use, distribution, and reproduction in any medium, provided the original work is properly cited. For citation use the DOI. For commercial re-use, please contact editor@chitrolekha.com 
away from Baroh, the journey brings forth beautiful hamlets, stunning flora and fauna, mango trees, and a handful of schools and shops.

Devoted to the Hindu God Lord Krishna and his consort Radha, this temple is visited by many pilgrims and tourists every day. Built during the 1980 s by a local follower and philanthropist named B. R. Sharma, this temple is made of white marble and is famous for having the largest amount of white marble used in any of the temples in Himachal Pradesh. The shikhara (temple tower) of the temple is typical of most temples found in North India.

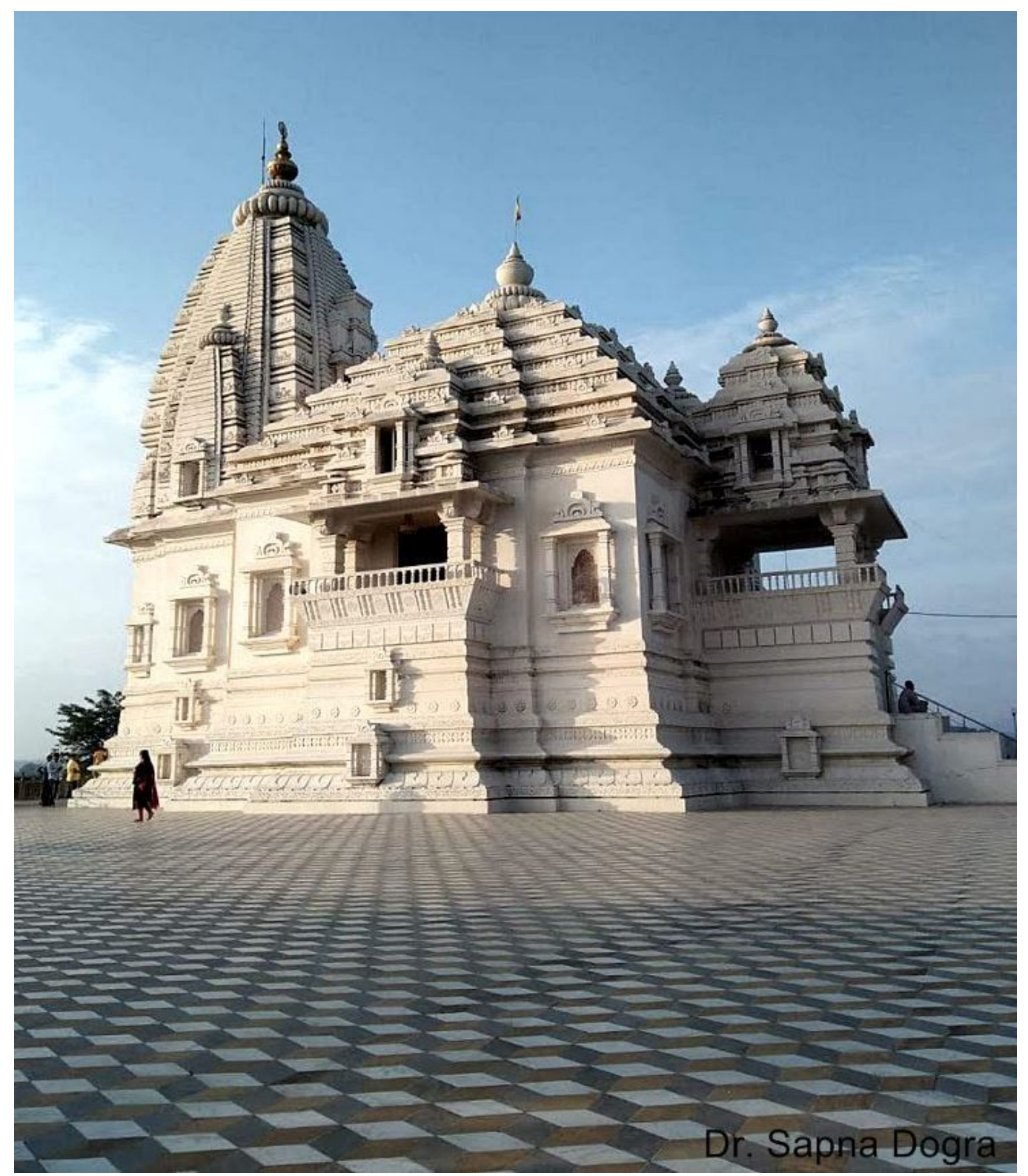

Side view of the Baba Baroh Temple.

As far as the temple architecture is concerned, the main temple has two floors. One floor has Radha Krishna idols and the second floor houses an idol of Goddess Durga. The temple premises also has an idol of Lord Hanuman. The architecture of the temple is a blend of modern and ancient South Indian design. The brilliant architectural skills are worth 
watching. Inside the temple is a balcony from where the devotees get a dual view of both the idols. The temple is spacious with a well-constructed langar hall. There are some other social welfare works being done by this temple such as maintaining cow shelter and offering Langar Seva. During the navratri (nine nights Hindu festival) the temple offers bhandara (food as a worship offering) to the devotees that consist of Kangri Dham. Kangri Dham (traditional and festive meal of Kangra) is cooked only by botis (a particular caste of Brahmins). The food is served on leaf plates called pattlu (in local language). The Dham includes plain steamed rice, rajma (kidney beans madra), dal (lentils), and other items followed by khatta (sweet-sour gravy) and at the end meetha bhatt (sweet rice) which is served as a dessert.

Baba Baroh temple is not only visited for its religious importance, but also for its scenic surroundings. The temple commands a panoramic view of the Dhauladhar ranges. Mesmerizing views of the sunset is an added attraction, making it a preferred spot for the whole family. The temple is very clean and well maintained.

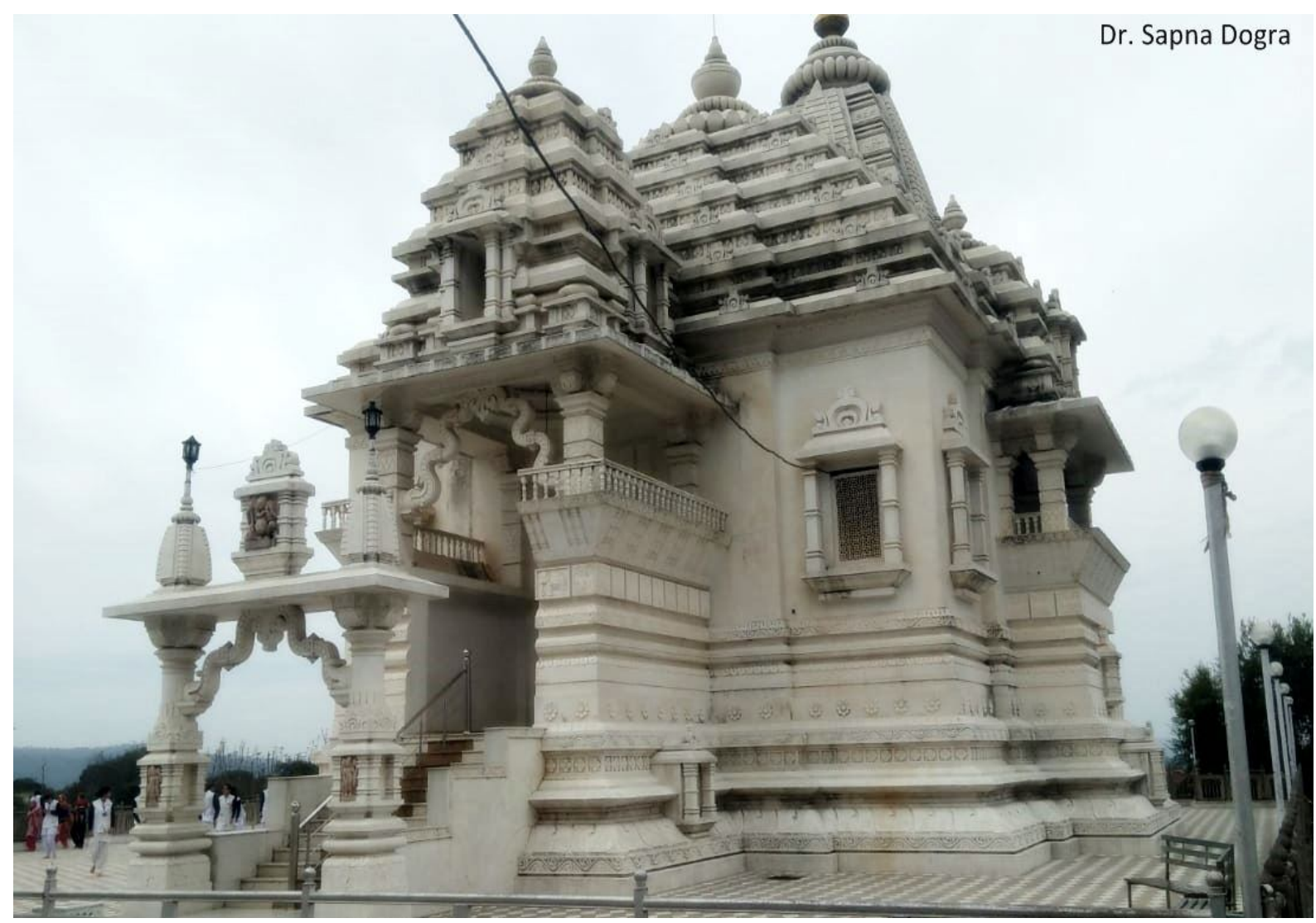

The entrance to the temple as one enters from the Baroh bus stand.

The temple can be also be reached by road after diverting from Pathankot Manali National Highway before Nagrotta Bagwan. If one is coming from Dharamshala, Kangra or Jawalaji then the link road from Kandi road is also one of the routes. By air, the Gaggal Airport is situated $14 \mathrm{~km}$ away from Dharamshala and $11 \mathrm{~km}$ from Kangra town respectively. The nearby railway station is Kangra. By road, the main bus terminal located at lower Dharamshala is the 
best place and is well connected to not only Baroh but all the major towns and cities of Himachal Pradesh, like Hamirpur, Chamba and Dalhousie.

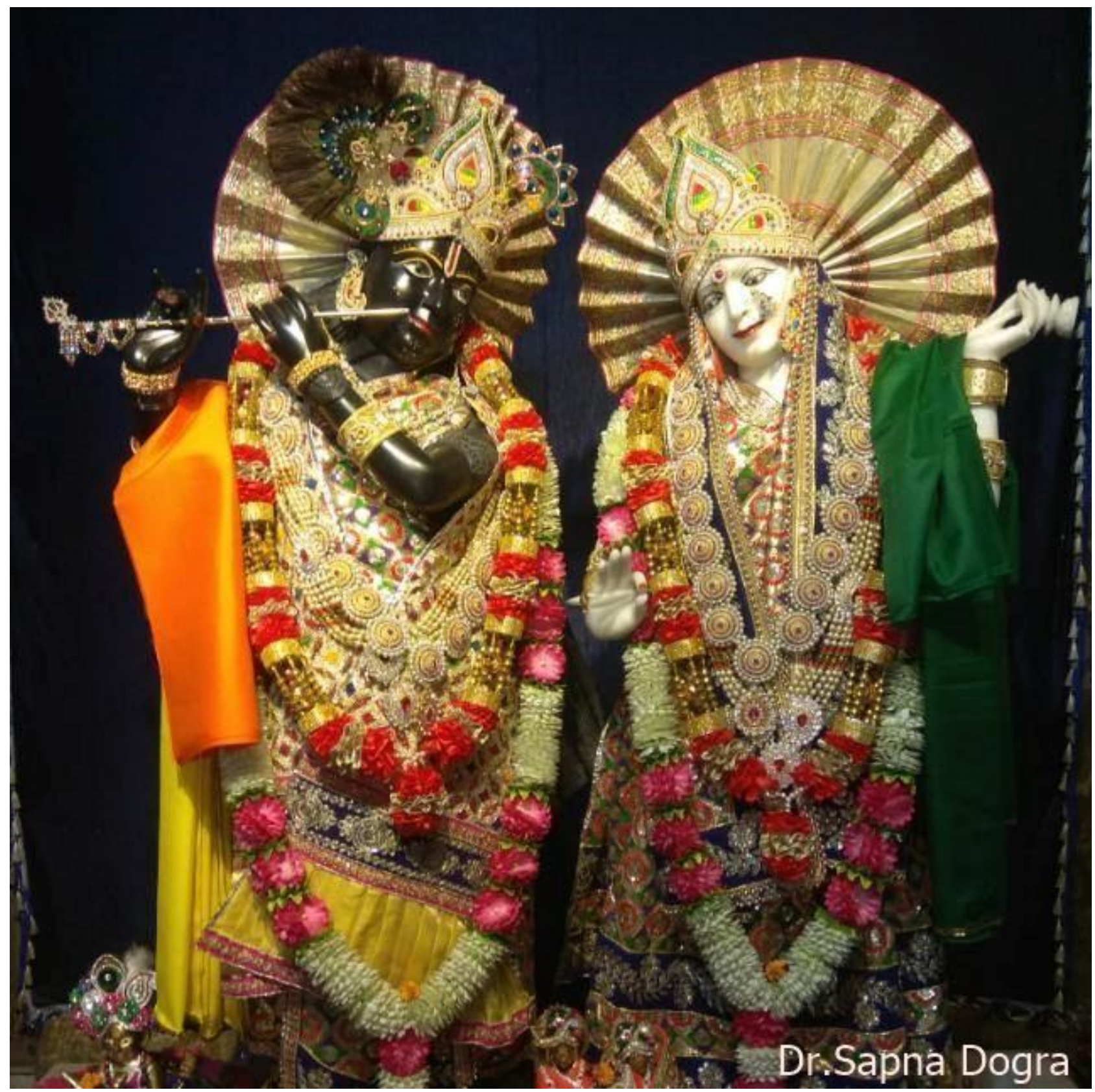

The marble idols of Radha Krishna placed inside the temple.

Every year Shri Krishan Janmashtami is celebrated with full joy here. During these times this white marble temple becomes more beautiful as its covered with decorative lights and festoons. The temple wears a vivacious aura during Janmashtami when the entire village comes to pay their respect to the deity. Local folk singers and kirtan mandalis (group of devotees that sing devotional songs) sing bhajanas (hymns) throughout the night making it a memorable day for the natives of Baroh and nearby areas. 


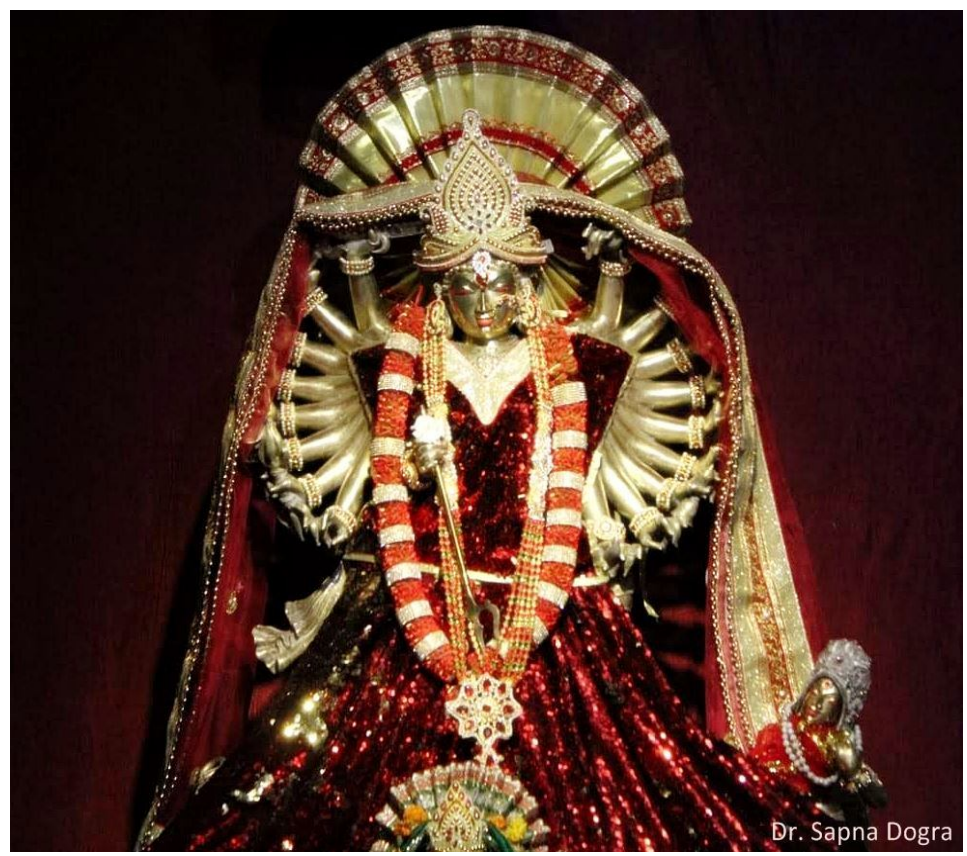

The idol of Goddess Durga placed inside the temple is made of metal.

Special prayers are offered in the morning and evening every day besides on special occasions and during festive seasons. Shri Krishan Janmashtami, Deepavali, Basant Panchami, Makara Sankranti, Maha Shivaratri, Vaisakha Sankranti and Shraavana Mondays are celebrated with zeal and splendour. Most important festivals are a major social and public event. The temple is also a popular meeting point for the students of Government Degree College and schools nearby. On Sundays, one can find innumerable families from villages near the temple premises.

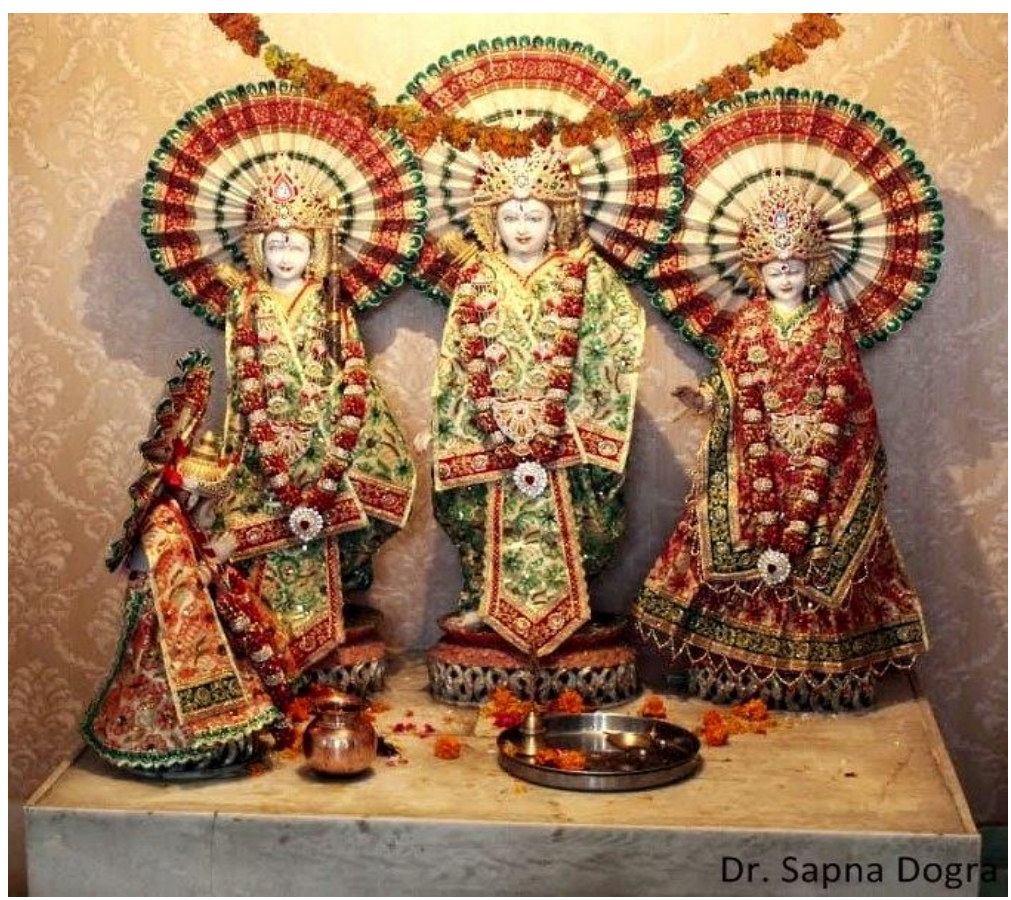

The idols of Lord Rama, Goddess Sita, Lakshmana and Lord Hanuman placed in the main temple. 
Though the weather in Kangra is quite pleasant throughout the year, a few months of summers from June till September can be oppressive because of the soaring temperature. The best time to visit the temple is in the month of October during the Dussehra festival which is celebrated with great gaiety and fervour in the Kangra Valley.

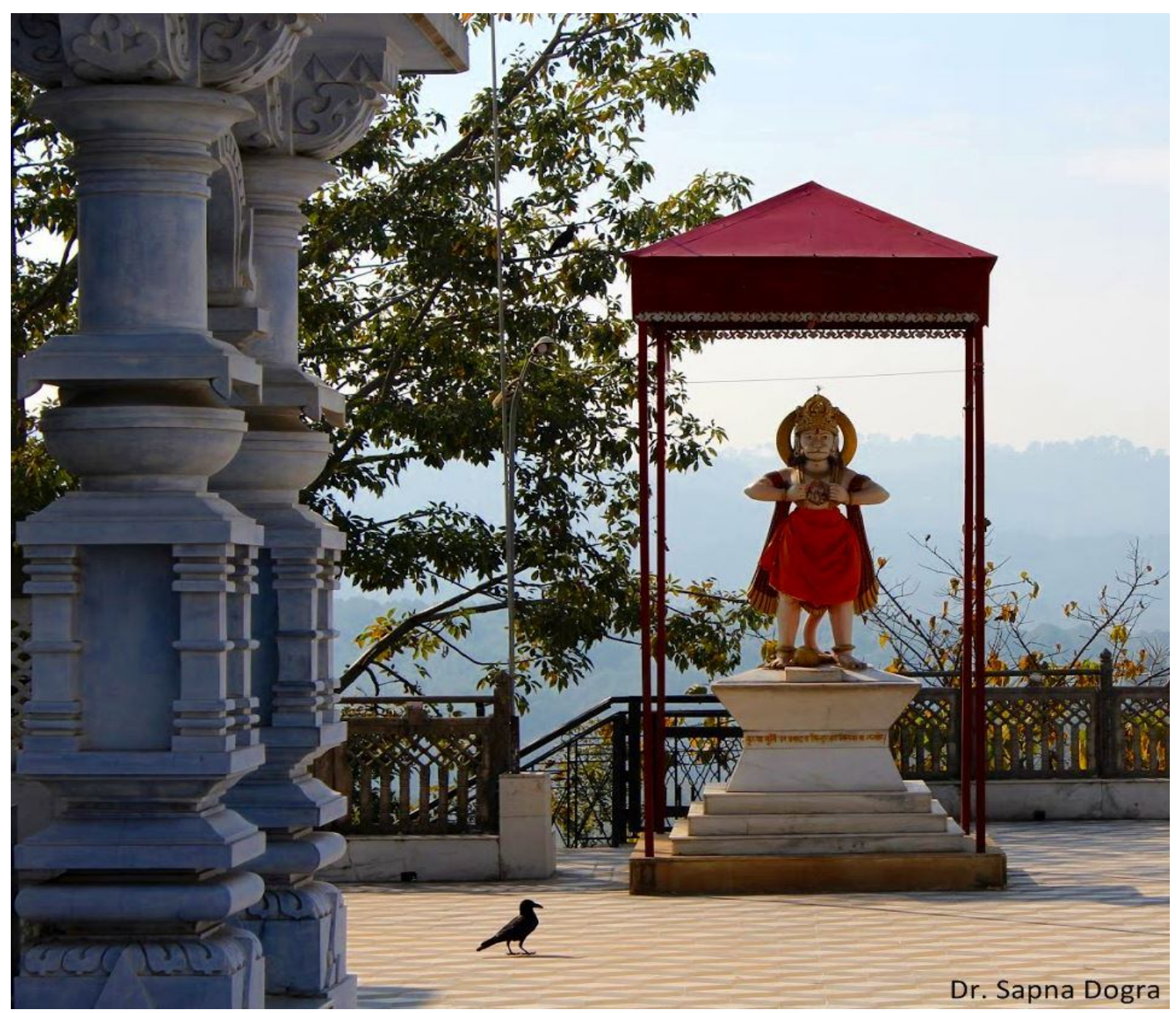

A Lord Hanuman idol in the temple premises.

Besides the main building of the temple, there are some smaller shrines in the courtyard. A very conspicuous figure is that of a Lord Hanuman, some distance behind the main shrine. Behind the Hanuman idol are stairs that lead to a very spacious langar hall. Facilities like drinking water and washrooms are also provided below the langar hall. Like many other Hanuman temples in India, an endless number of monkeys can be seen at this temple also. Pilgrims offer fruits and biscuits to these monkeys which are readily accepted by them. 
7 | Radhe Krishna Temple of Baroh, Kangra: A Photo Journey

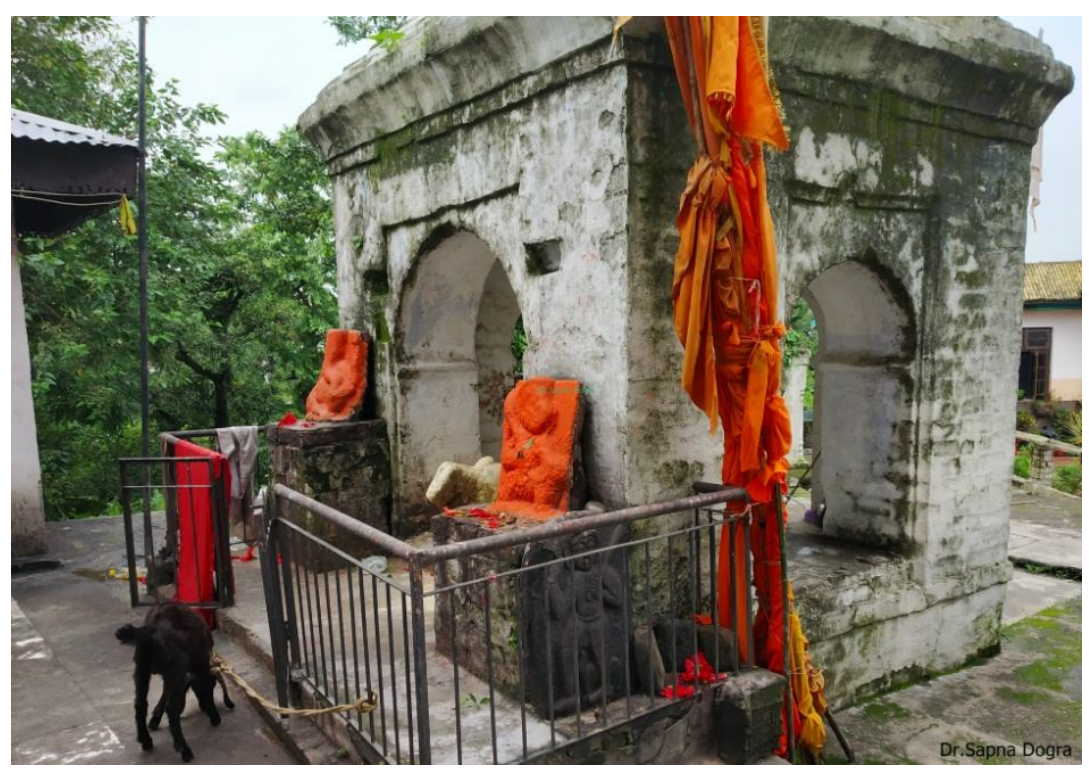

A part of an ancient shrine devoted to Kali Nath Bhole Shankar. This shrine is situated in proximity to Baba Baroh Temple.

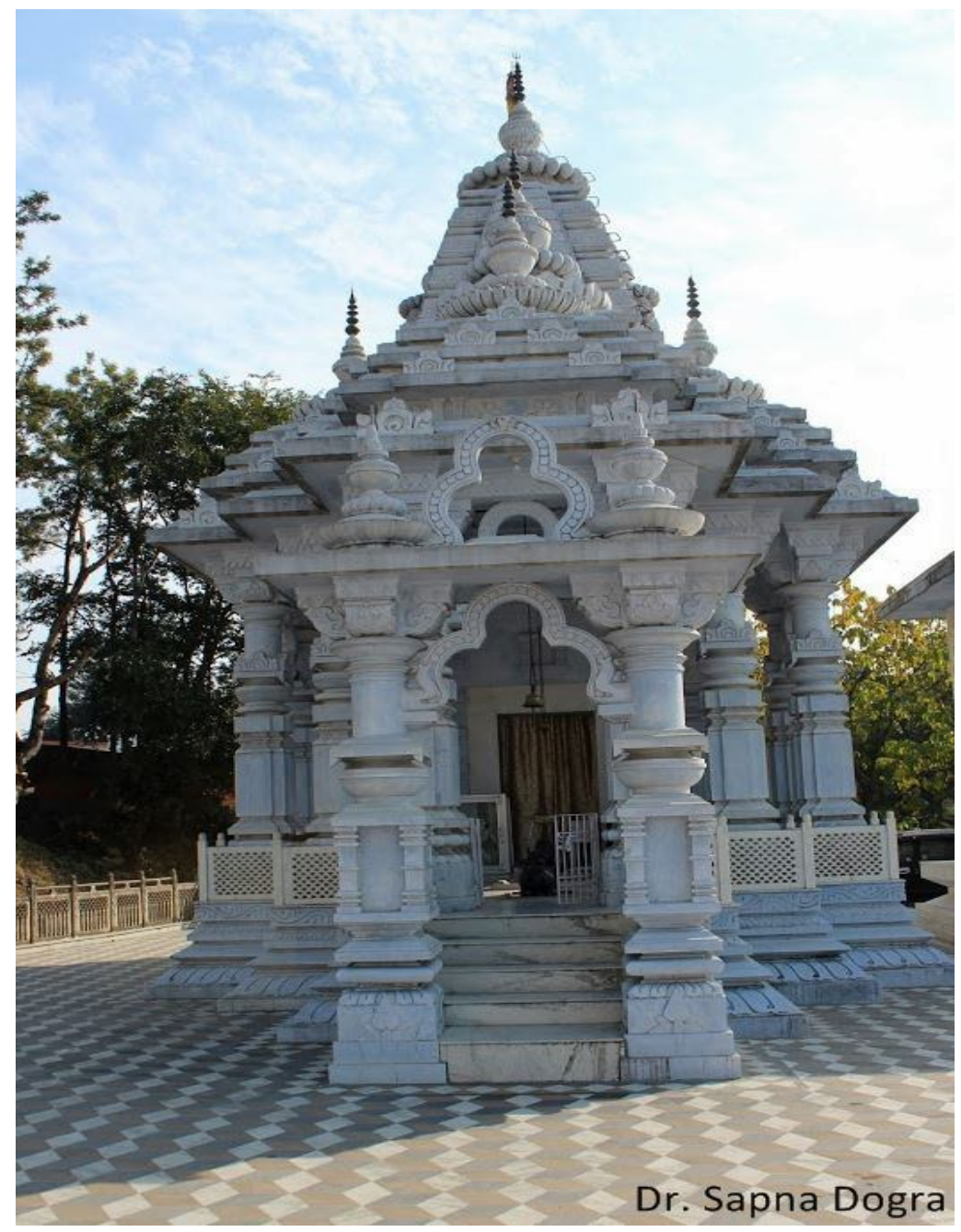

While the main temple stands in the temple premises, at the other corner, there is a temple of Lord Shiva. 
There are various other temples located nearby including the Nag temple in Ranital, Baba Fattu temple near Jassai which can be clubbed while visiting Baba Baroh Temple. Near Baba Baroh temple is an old shrine devoted to Kali Nath Bhole Shankar. Pilgrims make it a point to visit this shrine as well while visiting Baba Baroh temple.

One must bear in mind that it is because of Radhe Krishna Temple that this area, also known as 'Changar' in the local language, has managed to make a name for itself as a tourist destination. If at all this rural area had developed in the past decade, it can be surmised that it is primarily because of this temple. Even though it is difficult to reach this temple, owing to pot holed narrow roads and lack of other amenities, it is observed that Krishna devotees from all corners of India throng to this temple attracted by its beauty and architecture.

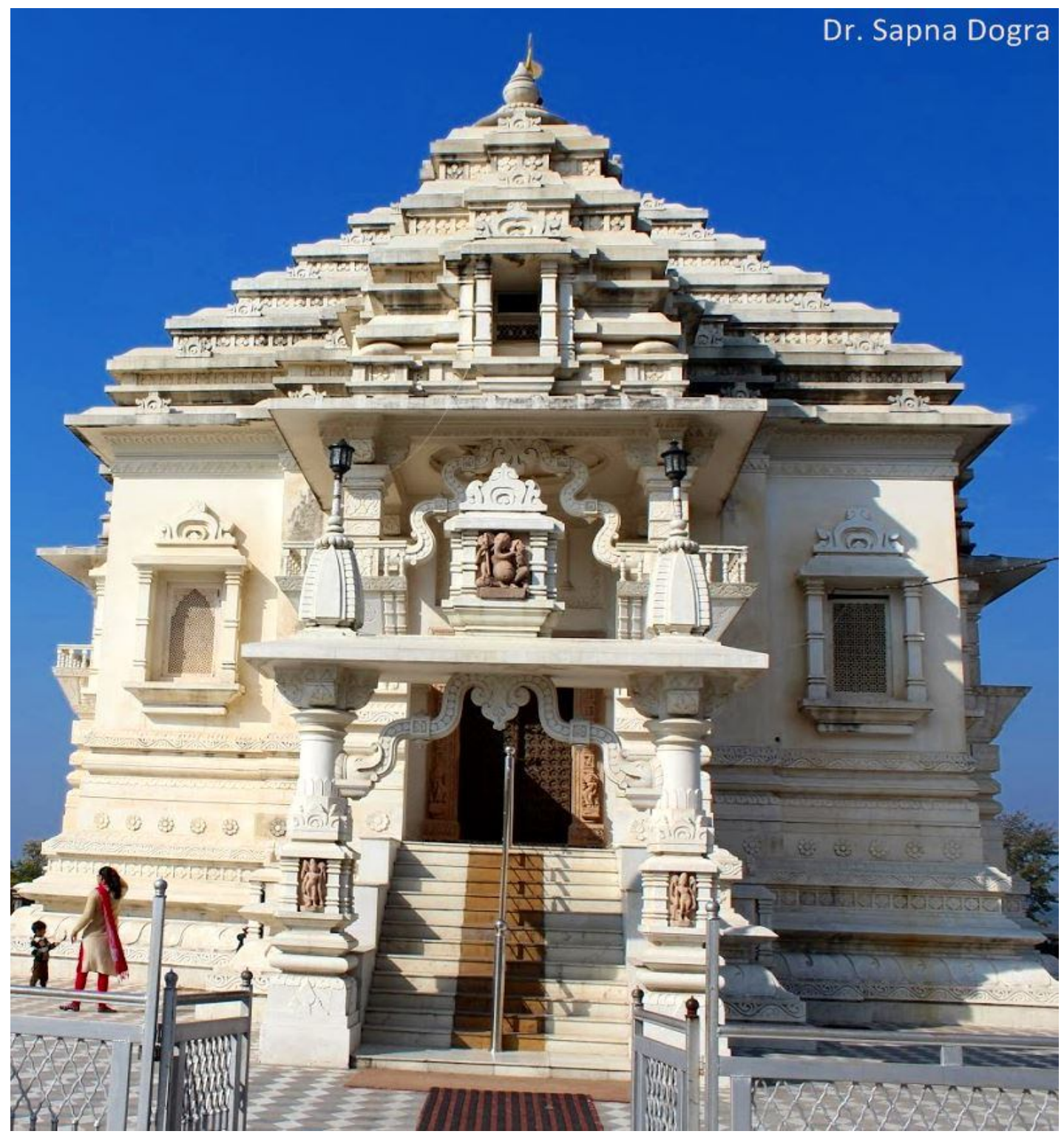

The entrance is adorned by intricate artwork and figures of other gods and goddesses like Lord Ganesh on the top and female figurines on either side of the main door. 
9 | Radhe Krishna Temple of Baroh, Kangra: A Photo Journey

The overall design of this shrine is beautiful and it is a must visit for anyone coming to Kangra. The peace and harmony of the place are without comparison. The quiet of the nature conjoined with interesting flora and fauna and stunning scenes of the Dhauladhar range of the Himalayas would be an unforgettable experience for those who wish to go far from the maddening crowd and the din of the cities. 